\title{
Instructional Characteristics of Information Literacy Programs in the First Year of College
}

\author{
Jennifer R. Keup, Ryan D. Padgett, Cindy A. Kilgo, \& Anne-Marie Deitering
}

Drawing from a national sample of 465 institutions, this descriptive study explores the instructional and pedagogical characteristics of course-based information literacy (IL) education in the first year of college. These national data indicate that information literacy instruction is an institutional priority for first-year students but that delivery methods, pedagogy, and evaluation of student learning outcomes rely upon more traditional approaches, such as IL instruction in English courses and first-year seminars; librarians as the primary content developers and instructors; classroom activities, lectures, research papers, and presentations as common instructional tools; and an underutilization of information technologies. While analyses of institutional practices suggest emerging areas of information literacy instruction, these strategies have yet to gain prominence on campuses across the country.

Higher education practitioners and scholars have long debated the purposes of higher education and the expectations of a college graduate. Despite this debate, current iterations of collegiate learning outcomes regularly include some reference to the ability to "identify, locate, evaluate, and effectively and responsibly use and share information" to address academic problems and practical issues (Rhodes, 2010, p. 36). Captured under the header of information literacy and defined by the American Library Association (1989) as the capacity "to recognize when information is needed and to have the ability to locate, evaluate, and use effectively the needed information," this skill has been identified as an essential outcome for college graduates (Brownell \& Swaner, 2010; Kuh, 2008); a component of many curricular and cocurricular student success interventions, such as first-year

Jennifer R. Keup (KEUPJ@mailbox.sc.edu) is the Director of the National Resource Center for The First-Year Experience and Students in Transition at the University of South Carolina and an affiliated faculty member in the Department of Educational Leadership and Policy in the College of Education at the University of South Carolina

Ryan D. Padgett is the Assistant Vice President for Enrollment and Student Success at Northern Kentucky University

Cindy A. Kilgo is a Graduate Research Assistant at the Center for Research on Undergraduate Education and doctoral student in the Higher Education program at the University of Iowa 
seminars, learning communities, undergraduate research, and senior capstone experiences (Boff \& Johnson, 2002; Leskes \& Miller, 2006; Padgett \& Kilgo, 2011; Young \& Hopp, 2014); and a competency area sought by employers (Hanneman \& Gardner, 2010; Hart Research Associates, 2010).

Given the importance of this skill, it is not surprising that research shows evidence of curricular activity around information literacy in the first year of college long before the 21st century. Even before most American colleges and universities offered first-year seminars or formalized first-year experience programs, composition courses for entering students were a mainstay of library instruction programs. Barclay and Barclay (1994) traced the relationship between bibliographic instruction (a precursor to information literacy) and freshman composition back to 1938 and concluded that "the freshman writing course remains the most important vehicle for providing BI (bibliographic instruction) in the academic library" (p. 216). More current literature focuses on librarians who teach information literacy and their collaboration with a classroom faculty colleague to design a one-time instruction session in a structured program or curriculum. For instance, Alfino, Pajer, Pierce, and Jenks (2008) described a sequence of assignments designed by a team that included librarians to lead students through the research process in a first-year composition (FYC) course linked with a critical thinking course. In another study, Brady, Singh-Corcoran, Dadisman, and Diamond (2009) reported on collaboration between librarians, English faculty members, and writing center tutors that resulted in both a FYC course with a scaffolded set of research assignments and a research and writing clinic, which colocated research and writing support. Held (2010) demonstrated that this work is not limited to the face-to-face environment by describing a project combining tutorials and an online research log to integrate information literacy into an FYC course delivered online. Finally, a series of articles by librarians and FYC faculty at Oregon State University show that this collaborative process is iterative and contingent upon mutuality of purpose and a shared understanding between librarians and instructors of research writing as equal partners in a scholarly conversation (Deitering \& Jameson, 2008; McMillen \& Hill, 2004).

Several institutionally based studies have examined the delivery method and instructional content of information literacy education approaches. For example, librarians at Washington State University found success reaching out to various constituents via a host of methods, including door hangers in the residence halls, library tours during orientation, and library scavenger hunts (Cummings, 2007; Kasbohm, Schoen, \& Dubaj, 2006; Marcus \& Beck, 2003). Other studies document the effectiveness of information literacy tutorials in academic libraries (ShiaoFeng \& Kuo, 2010; Somoza-Fernandez \& Abadal, 2009), with particular emphasis placed on the Texas Information Literacy Tutorial (TILT) at the University of Texas at Austin as a model program (Orme, 2004; Prouse, 2005). The literature also identifies librarian-led instructional modules in first-year seminars as a common delivery method for information literacy content, which not only facilitate the development of information literacy in students but also results in an increased appreciation of expertise between faculty and librarians, enhancement of teaching- 
related development opportunities for librarians, and greater understanding among librarians of students' needs, challenges, and abilities (Frazier, 2006; Sugarman \& Mosby, 2002).

In one of the few studies drawing upon a broader sample, Boff and Johnson (2002) collected survey data from 368 institutions "to examine the library component of FYE courses nationwide" (p. 279). Findings from this study provided a more comprehensive portrait of information literacy instruction in the first year, most notably through first-year seminars, than had previously been captured. These researchers found that well over three-quarters of institutional respondents reported that a library component was a part of their first-year seminar curriculum; two-thirds indicated that it was a required component of the course, and over half stated that more than one hour of in-class time was dedicated to the topic of information literacy (Boff \& Johnson, 2002). Survey results also showed that the content of information literacy instruction in first-year seminars focused on the use of tools to access information, navigation of the library facility, and research skills and that this content was largely developed and delivered by librarians, first-year experience directors, or first-year seminar instructors and often represented a collaboration between all three (Boff \& Johnson, 2002). Finally, correlation analyses with these data showed that highly selective schools were less likely to require the library component in first-year experience courses, devoted less in-class time to this topic, and more frequently integrated content related to navigating the library facility (tours and scavenger hunts) into information literacy content than institutions with medium and low selectivity standards (Boff \& Johnson, 2002).

While informative, this body of research on information literacy has overrelied upon institution-specific studies, which limits the generalizability of the findings and doesn't provide a comprehensive portrait of institutional practices and instructional strategies for teaching information literacy to undergraduates. Further, each study is only able to focus on the range of instructional vehicles for information literacy available at that institution, most commonly firstyear seminars, rather than examine and compare a fuller range of information literacy content delivery methods. The current study draws from a national sample of institutions to explore the instructional characteristics and strategies for information literacy education during the first year of college. In particular, this study focuses on information literacy instructional strategies, modules, or components that are based in a first-year course, classroom, or curriculum.

\section{Methods}

This study was part of the National Survey of Information Literacy Programs in the First Year, which represented a partnership between the National Resource Center for The First-Year Experience and Students in Transition and the Association of College Research Libraries (ACRL), a division of the American Library Association (ALA). An online questionnaire gathered data at the institution level and included 20 items that measured methods of information literacy instruction 
in the first year, pedagogical approaches, reach and scope of the program on campus, learning outcomes, instructional content, instructors, and student and program assessment strategies.

All librarians listed as members of the Instruction Section of ACRL were sent an e-mail invitation to complete the questionnaire in fall 2011. Of the 3,684 contacts who received the online instrument, 578 individuals responded for a 16\% response rate. The institutional sample for the current study underrepresented two-year institutions, slightly overrepresented public institutions, and included far fewer campuses with enrollments of 5,000 or fewer and many more institutions of 15,000 or more undergraduates when compared to national data for these characteristics. Despite these limitations in the dataset, this study represents the most comprehensive portrait of institutional practice and campus programming related to information literacy in the first year that has been captured to date. Given the exploratory nature of the study, the primary analyses for the current research were descriptive and included means, frequency distributions, and cross tabulations.

\section{Results}

Analyses from survey data provide evidence that the majority of institutional respondents reached a wide range of first-year students with formalized information literacy (IL) efforts. Only $9 \%$ of respondents reported that they reached $20 \%$ or less of first-year students on their respective campuses with formal IL instruction, $73.2 \%$ reached at least half of their first-year class, and $27.6 \%$ of respondents indicated that at least $90 \%$ of their first-year students received some type of IL instruction. These data also indicate that slightly less than half $(47.5 \%)$ of institutions report that all of their first-year students are required to engage in an information literacy course, module, or component.

Survey respondents also were asked to identify all of the instructional formats in which information literacy content was delivered to first-year students. In addition, given that multiple approaches exist on campuses, the survey asked respondents to indicate the information literacy courses, modules, and components that reached the highest number of first-year students and, thus, represented the primary delivery method. Table 1 summarizes the institutional responses for the use of six course-based instructional formats for information literacy content delivery. Noted therein, course-based models, particularly within an English course or first-year seminar, were commonly identified as an IL instructional strategy for first-year students, and these two course-based IL methods were regularly reported as the primary IL delivery method for campuses in this study. Conversely, while campuses reported learning communities, independent IL courses, and freshman interest groups as one of many course-based strategies for information literacy content delivery in the first year, they were rarely used as primary methods at these institutions.

More specifically, nearly three quarters of institutional respondents reported that students received IL content in English courses (including Composition), and 


\section{Primary Course-Based Delivery Methods for Information Literacy in the First Year}

\begin{tabular}{lcc} 
Information literacy (IL) program & $\begin{array}{c}\text { \% reporting as one } \\
\text { of the IL delivery } \\
\text { methods offered }\end{array}$ & $\begin{array}{c}\text { \% reporting as } \\
\text { primary IL } \\
\text { delivery method }\end{array}$ \\
\hline Within an English course & 72.3 & 32.1 \\
Within a first-year seminar & 59.4 & 30.6 \\
Within another type of first-year course & 29.7 & 11.7 \\
Learning community & 19.8 & 0.5 \\
Within an independent information literacy course & 18.7 & 3.6 \\
Freshman interest groups (FIGS) & 4.1 & 0.5 \\
\hline $\begin{array}{l}\text { N }=445 \text { institutions. *Percentages will add to more than } 100 \text { since respondents were asked to "mark all } \\
\text { that apply." }\end{array}$
\end{tabular}

almost one third reported that these partnerships were their primary method of IL instruction. These findings confirm that the pattern of historic collaboration between English courses, composition curricula, and information literacy widely noted in institutional studies persists. The current data also confirms Boff and Johnson's (2002) finding that first-year seminars are an important vehicle for information literacy instruction; well over half of survey respondents indicated it was one of the delivery strategies for IL content, and more than $30 \%$ identified it as the primary delivery method. Further, these survey data suggest that institutions are beginning to experiment with other first-year courses as venues for information literacy instruction and even to create first-year courses dedicated specifically to this topic, although they have yet to reach a position of prominence on most campuses and tend not to reach large populations of first-year students at these institutions. Results also indicate that learning communities, including freshman interest groups, are an underutilized curricular structure for providing IL instruction to firstyear students.

The National Survey of Information Literacy Programs in the First Year also provided a range of findings regarding IL instructional staffing, content delivery, and pedagogy. These data show that librarians were chiefly responsible for information literacy program development and were overwhelmingly selected as the primary information literacy instructor (at $88.0 \%$ of institutions in the sample), regardless of the type of program being offered. In a distant second position, $9.9 \%$ of information literacy programs were taught by non-librarian faculty, followed by graduate students $(4.1 \%)$ and a program or course coordinator $(2.8 \%)$. The majority of IL instruction occurred in real-time, in-person format. 
However, $10.3 \%$ of indicated that their course management was a principle vehicle for IL content delivery; $10.5 \%$ of institutions reported that at least some of their information literacy courses, modules, or components were taught in an onlineonly format; and $25.4 \%$ utilized blended (part classroom, part online) methods as at least one of several models for delivering IL content. Finally, when institutions were asked to select the top three primary instructional methods for conveying IL content, several common strategies emerged, including active learning exercises (at $61.7 \%$ of institutions in the sample), lectures (45.2\%), orientation sessions (31.6\%), library-designed research assignments $(28.6 \%)$, tutorials $(18.3 \%)$, and small-group work (17.8\%). Conversely, less than two percent of respondents reported that polling software, wikis, social networking tools, blogs, podcasts, and role-playing were primary IL instructional methods, suggesting that technologyrelated tools are particularly under represented in the delivery of IL content to first-year students.

The survey also asked institutions to report the means by which IL skills were assessed among first-year students. As Table 2 indicates, the measurement of IL skill development and learning is most often conducted through traditional knowledge assessments, such as research papers, annotated bibliographies, and presentations. These findings are encouraging because they suggest that students are being asked to put these skills into practice and to demonstrate IL competency, rather than simply being tested with a quiz, worksheets, or other busy work. However, a mix of more innovative learning evaluations, such as portfolio assessments; video or digital media productions; or web-page, blog, or wiki projects were employed to a lesser degree. When interpreting these findings, it is important to note that survey responses indicate how frequently these measures are used to demonstrate knowledge, but they do not address whether outcomes related to IL instruction are directly assessed or whether feedback about IL competency is effectively communicated to the student.

\section{Discussion}

This study sought to provide a comprehensive portrait of information literacy (IL) instruction in the first college year. Drawing from the largest national sample of IL institutional practices gathered to date, these analyses indicate that information literacy is a priority in the first year of college at colleges and universities across the country. Further, findings from these data validated institutional findings from the body of previous literature on this topic, thereby adding generalizability and validity to this body of work. Most notably, English classes and first-year seminars remain important course-based vehicles for information literacy instruction, and librarians continue to serve as the key developers and purveyors of information literacy content in the first year. Further, these findings show a heavy reliance on traditional methods of IL content delivery in the classroom and assessment of students' information literacy competency, such as lectures, classroom exercises, research assignments, papers, and presentations. 


\section{Methods of Demonstrating Information Literacy Competency and Knowledge}

Method

Research paper

Annotated bibliography

Student presentation

Pretest and posttest

Other

Quizzes

Portfolio assessment

Video production or digital media production

Web-page project

Blog project

Poster session

None

Wiki project

Brochure
Percent

56.6

40.4

34.2

22.8

22.6

21.9

9.7

7.1

5.8

5.2

5.2

4.7

3.9

2.2

$\mathrm{N}=445$ institutions. * Percentages will add to more than 100 since respondents were asked to "mark all that apply."

Findings from analyses of data drawn from the 2011 National Survey of Information Literacy in the First Year also highlight aspects of information literacy education that were relatively absent from previous research. For instance, the instrument sought to capture new data about IL content delivery, including innovative and emergent methods. Analyses indicate that independent information literacy courses appear to be an evolving structure for IL delivery, IL literacy has begun to cross-over into first-year courses outside of English classes and firstyear seminars, and learning communities represent a curricular structure ripe for further development and use with respect to IL content delivery. In addition, this study explored the use of various IL instructional methods, which documented the current prominence of classroom-based pedagogies, such as active learning exercises, librarian-designed research assignments, and small group work. This survey also examined national trends with respect to assessing student competency on information literacy skills. Results of these analyses showed an institutional tendency toward traditional methods, such as research papers, annotated bibliographies, presentations, and quizzes, and less engagement of innovative learning evaluations, especially those that used technological platforms. 
While these results highlight fledgling directions for IL instruction, survey responses generally showed that institutions are still engaging the same types of IL instructional practices and content delivery for first-year students that have been used for years, such as a heavy reliance on lectures, one-shot instructional opportunities, classroom modules, research papers, and presentations. As such, the findings from the 2011 National Survey of Information Literacy in the First Year represent a clarion call to librarians and especially to faculty and staff in first-year experience programs to take up the mantle of leadership toward developing engaging pedagogies and engaging innovative instructional techniques for information literacy instruction among entering students. Based upon the history of FYE programs as a vehicle to build connections across academic and student affairs; define new learning spaces such as residence halls, career services, and health and wellness facilities; and set standards and precedents for effective delivery of high-impact practices in the first year of college, they would appear to be uniquely equipped to take information literacy instruction to the next level for the current and future generations of first-year students.

Together, these results validate previous findings from institutional studies, represent an exploration of instructional aspects of information literacy in the first year that were not addressed in previous work, and identify emergent practices and areas of opportunity that can inform the development and delivery of these programs on campuses and in future studies on this topic.

\section{References}

Alfino, M., Pajer, M., Pierce, L., \& Jenks, K. O. (2008). Advancing critical thinking and information literacy skills in first year college students. College \& Undergraduate Libraries, 15(1/2), 81-98.

American Library Association. (1989). Presidential committee on information literacy: Final report. Association of College \& Research Libraries. Retrieved from http://www.ala.org/acrl/publications/whitepapers/presidential

Barclay, D. A., \& Barclay, D. R. (1994). The role of freshman writing in academic bibliographic instruction. Journal of Academic Librarianship, 20(4), 213-217.

Boff, C., \& Johnson, K. (2002). The library and first-year experience courses. Reference Services Review, 34(4), 277-287.

Brady, L., Singh-Corcoran, N., Dadisman, J. A., \& Diamond, K. O. (2009). A collaborative approach to information literacy: First-year composition, writing center, and library partnerships at West Virginia University. Composition Forum, 19, 1-18.

Brownell, J.E. \& Swaner, L.E. (2010). Five high-impact practices: Research on learning outcomes, completion, and quality. Washington, DC: Association of American Colleges and Universities (AAC\&U).

Cummings, L. U. (2007). Bursting out of the box: Outreach to the millennial generation through student services programs. Reference Services Review, 35(2), 285-295. 
Deitering, A.-M., \& Jameson, S. (2008). Step by step through the scholarly conversation: A collaborative library/writing faculty project to embed information literacy and promote critical thinking in first-year composition at Oregon State University. College \& Undergraduate Libraries, 15(1/2), 57-79.

Frazier, N. E. (2006). In the loop: One librarian's experiences teaching within firstyear learning communities. College \& Undergraduate Libraries, 13(1), 21-31.

Hanneman, L., \& Gardner, P. D. (2010). CERI Research Brief 1-2010. Retrieved from http://www.ceri.msu.edu/wp-content/uploads/2009/10/skillsabrief1-2010.pdf.

Hart Research Associates (2010). Raising the bar: Employers' views on college learning in the wake of the economic downturn. Washington, DC: Hart Research Associates.

Held, T. (2010). Blending in: Collaborating with an instructor in an online course. Journal of Library \& Information Sciences in Distance Learning, 4, 153-165.

Kasbohm, K. E., Schoen, D., \& Dubaj, M. (2006). Launching the library mystery tour: A library component for the first-year experience. College \& Undergraduate Libraries, 13(2), 35-46.

Kuh, G.D. (2008). High-impact educational practices: What they are, who has access to them, and why they matter. Washington, DC: Association of American Colleges and Universities (AAC\&U).

Leskes, A. \& Miller, R. (2006). Purposeful pathways: Helping students achieve key learning outcomes. Washington, DC: Association of American Colleges and Universities (AAC\&U).

Marcus, S., \& Beck, S. (2003). A library adventure: Comparing a treasure hunt with a traditional freshman orientation tour. College \& Research Libraries, 64(1), 23-44.

McMillen, P. S., \& Hill, E. (2004). Why teach "research as a conversation" in freshmen composition courses? A metaphor to help librarians and composition instructors develop a shared model. Research Strategies, 20(3), 3-22.

Orme, W. A. (2004). A study of the residual impact of the Texas information literacy tutorial on the information-seeking ability of first year college students. College \& Research Libraries, 65(3), 205-215.

Padgett, R.D. \& Kilgo, C.A. (2012). 2011 National Survey of Senior Capstone Experiences: Institutional-level data on the culminating experience (Research Reports on College Transitions No. 3). Columbia, SC: University of South Carolina. National Resource Center for The First-Year Experience and Students in Transition.

Prouse, M. R. (2005). The impact of online delivery of literacy skills instruction on the content as perceived by the students at the Wilmington and Stanton campuses of Delaware Technical \& Community College. New Castle, DE: Wilmington College.

Rhodes, T.L. (Ed.; 2010). Assessing outcomes and improving achievement: Tips and tools for using rubrics. Washington, DC: Association of American Colleges and Universities (AAC\&U).

Shiao-Feng, S., \& Kuo, J. (2010). Design and development of web-based information literacy tutorials. Journal of Academic Librarianship, 36(4), 320-328. 
Somoza-Fernandez, M., \& Abadal, E. (2009). Analysis of web-based tutorials created by academic librarians. Journal of Academic Librarianship, 35(2), 126-131.

Sugarmam, T., \& Mosby, A. P. (2002). Making a weak link stronger: Incorporating information literacy into a semester-long freshman seminar. Georgia Library Quarterly, 39(2), 12-6.

Young, D.G. \& Hopp, J.M. (2014). 2012-2013 National Survey of First-Year Seminars: Exploring high-impact practices in the first college year. (Research Reports on College Transitions No. 4). Columbia, SC: University of South Carolina, National Resource Center for The First-Year Experience and Students in Transition. 